\title{
ANALISA KOMPARASI JUMLAH SERAPAN PEMBANGUNAN BERDASARKAN ASPIRASI MASYARAKAT MELALUI MUSRENBANG DAN RESES
}

\author{
Ani Pujiati \\ Fakultas Ekonomi Universitas Sang Bumi Ruwa Jurai \\ ani.pujiati@fe.saburai.ac.id
}

\begin{abstract}
Abstrak. Tuntutan penyelenggaraan pemerintah yang demokratis diantaranya adalah dalam proses pembangunan yang partisipatif dan efisien dalam penyelenggaraan sistem pemerintahan dari tingkat yang tertinggi hingga yang terendah. Untuk mengakomodir hal tersebut Pemerintah Pusat merespon situasi ini dilaksanakannya desentralisasi penyelenggaraan pemerintahan secara nyata. Penelitian yang dilakukan berupa studi kasus tentang proses penyusunan APBD Kabupaten Pesawaran Tahun Anggaran dan serapan aspirasi masyarakat melalui mekanisme Musrenbang dan Reses yang dilakukan Pemerintah Kabupaten Pesawaran. Aspirasi masyarakat atau stakeholders melalui musrenbang telah terserap dalam APBD, jumlah masukan yang diajukan masyarakat melalui mekanisme musrenbang sebanyak 658 kegiatan dan telah dianggarkan dalam APBD Tahun anggaran 2018 sebanyak 410 Kegiatan atau $62.3 \%$, sisa kegiatan yang tidak atau belum terakomodir dalam APBD Tahun Anggaran 2018 sebanyak 245 Kegiatan atau 37,7 \%. Aspirasi masyarakat atau stakeholders melalui Reses telah terserap dalam APBD, jumlah masukan yang diajukan masyarakat melalui mekanisme Reses sebanyak 93 kegiatan dan telah dianggarkan dalam APBD Tahun anggaran 2018 sebanyak 35 Kegiatan atau 38,46\%, sisa kegiatan yang tidak atau belum terakomodir dalam APBD Tahun Anggaran 2018 sebanyak 248 Kegiatan atau 62,54 \%.
\end{abstract}

Kata kunci: Aspirasi, Komparasi, Musrembang, Reses.

\section{PENDAHULUAN}

Tuntutan penyelenggaraan pemerintah yang demokratis diantaranya adalah dalam proses pembangunan yang partisipatif dan efisien dalam penyelenggaraan sistem pemerintahan dari tingkat yang tertinggi hingga yang terendah. Untuk mengakomodir hal tersebut Pemerintah Pusat merespon situasi ini dilaksanakannya desentralisasi penyelenggaraan pemerintahan secara nyata. Desentralisasi adalah penyerahan wewenang pemerintahan oleh pemerintah pusat kepada daerah otonom yang dijawantahkan dalam Undang-undang Nomor 9 Tahun 2015 tentang Perubahan Kedua Atas Undangundang Nomor 23 Tahun 2014 Tentang Otonomi Daerah.

Dalam daerah otonom, masyarakat membentuk pemerintahan daerah otonom.
Pemerintahan daerah otonom merupakan pemerintahan daerah yang badan pemerintahannya dipilih oleh penduduk (masyarakat) setempat dan memiliki kewenangan untuk mengatur dan mengurus urusannya sendiri(Nurcholis, 2005: 20).

Aspirasi dalam kamus besar bahasa indonesia bermakna harapan dan tujuan pada masa yang akan datang, jadi aspirasi masyarakat dalam pembangunan dapat dimaknai sebagai harapan dan tujuan masyarakat dimasa yang akan datang akan perubahan-perubahan yang akibatkan oleh pelaksanaan kegiatan Pemerintah Daerah sehingga berdampak kemajuan dan kesejahteraan.

Munir (2002) menegaskan hakikat dari pembangunan daerah yaitu : "Masalah pokok dalam pembangunan daerah terletak pada penekanan terhadap kebijakan pembangunan yang didasarkan pada 
kekhasan karakteristik daerah yang bersangkutan (endogenous development) dengan menggunakan potensi sumberdaya manusia, kelembagaan dan sumberdaya fisik secara lokal. Orientasi ini mengarahkan pada tumbuhnya inisiatif dan kreatifitas dari daerah dalam proses pembangunan ".

Penelitian mengenai Analisa Komparasi Jumlah Serapan Pembangunan Berdasarkan Aspirasi Masyarakat Melalui Musrenbang Dan Reses penting karena yang memahami kebutuhan daerah adalah masyarakat wilayah itu sendiri sehingga pembangunan akan lebih maksimal pelaksanaannya. Daerah diharapkan mampu untuk mengidentifikasi kebutuhannya sendiri, merumuskan tujuan pembangunan sendiri dan mampu mengkreasi strategi pencapaian tujuan.

Kamelus (2004) menyatakan untuk meningkatkan efektivitas dan efisiensi perencanaan dan penganggaran daerah maka perlu perbaikan proses perencanaan dan penganggaran antara lain yang terkait dengan alur proses perencanaan dan penganggaran serta sekuens penyusunan dokumen perencanaan dan penganggaran harus konsisten.

Dalam kaitannya dengan kualitas perencanaan pembangunan, penulis berpendapat bahwa perencanaan pembangunan yang berkualitas adalah perencanaan yang bisa memenuhi kebutuhan dan keinginan stakeholders dan konsisten dari tahap penyusunan agenda setting, penyusunan policy formulation dan penyusunan budgeting, sedangkan apabila perencanaan tidak memenuhi kedua hal tersebut maka dapat dikatakan bahwa perencanaan itu tidak atau belum berkualitas.

Pemerintahan daerah otonom merupakan pemerintahan daerah yang badan pemerintahannya dipilih oleh penduduk (masyarakat) setempat dan memiliki kewenangan untuk mengatur dan mengurus urusannya sendiri (Nurcholis, 2005: 20).

Menurut Bhenyamin Hoessein (2001,dalam Nurcholis 2005: 19) fungsi pembentukan kebijakan (policy making2function) yang dilakukan oleh pejabat yang dipilih melalui pemilu, sedangkan fungsi pelaksanaan kebijakan (policy executing function) dilakukan oleh pejabatyang diangkat/birokrat lokal, sehingga dalam pemerintahan daerah terdapat tiga faktor utama yaitu (1) masyarakat, (2) elected official / pejabat politik (kepaladaerah dan DPRD), dan (3) appointed officiall birokrasi. Penyerahan kewenangan yang diterapkan dalam otonomi daerah bersifat open end arrangement atau general competence.

\section{KAJIAN TEORI}

\section{Perencanaan Pembangunan}

Albert Waterston (1965) dalam "Development Planning", menyebutkan bahwa perencanaan pembangunan adalah: "melihat kedepan dengan mengambil pilihan berbagai alternatif dari kegiatan untuk mencapai tujuan masa depan tersebut dengan terus mengikuti agar supaya pelaksanaannya tidak menyimpang dari tujuan". Penetapan langkah-langkah yang strategis oleh pelaksana pembangunan juga sangat penting yang mendukung pelaksanaan kegiatan pencapaian tujuan pembangunan bisa tercapai dengan efektif dan efisien.

Menurut Riyadi dan Bratakusumah (2004:7) perencanaan pembangunan adalah suatu proses perumusan alternatif-alternatif atau keputusan-keputusan yang didasarkan pada data-data dan fakta-fakta yang akan digunakan sebagai bahan untuk melaksanakan suatu rangkaian kegiatan / aktivitas kemasyarakatan, baik yang bersifat fisik (material), maupun non fisik 
(mental dan spiritual) dalam rangka mencapai tujuan yang lebih baik.

\section{Musrenbang}

Musrenbang $\begin{gathered}\text { adalah } \\ \text { masyarakat roses } \\ \text { tentang }\end{gathered}$
musyawarah
pembangunan daerah yang di laksanakan
guna untuk mendapatkan suatu kesepakatan
di antara masyarakat di setiap daerah yang
akan di adakan pembangunan. Musrenbang
adalah forum di mana masyarakat dapat
menyampaikan aspirasi mereka, dalam
proses pembangunan yang akan
dilaksanakan tentang bagaimana yang
seharusnya dilakukan pemerintah serta
sebaliknya yang harus di lakukan
masyarakat dalam pembangunan yang akan
dilaksanakan.

Dasar Hukum Pelaksanaan

Musrenbang :

1. Undang-UndangNomor 27 Tahun 2003 tentangKeuangan Negara (Lembaran Negara Republik Indonesia Tahun 2003 Nomor 47, Tambahan Lembaran Negara Republik Indonesia Nomor 4286).

2. Undang-UndangNomor 25 Tahun 2004 tentang Sistem Perencanaan Pembangunan Nasional.

3. Undang-Undang No. 25 Tahun 2004 tentangSistemPerencanaan

Pembangunan NasionalUndangUndangNomor 32 Tahun 2004 tentangPemerintahan Daerah (Lembaran Negara Republik Indonesia Tahun 2004 Nomor 125,Tambahan Lembaran Negara Republik Indonesia Nomor 4437).

Musrenbang kabupaten/ kota merupakan puncak kegiatan musyawarah pembangunan yang diawali dari kegiatan Musrenbang Desa/ Kelurahan, Musrenbang Kecamatan, dan Forum OPD. Pada tingkat kabupaten kota Musrenbang bertujuan untuk mencapai consensus dan kesepakatan tentang draft final RKPD (Rencana Kerja PemerintahDaerah).

Proses musrenbang pada dasarnya mendata aspirasi dan kebutuhan masyarakat yang dirumuskan melalui pembahasan di tingkat desa/kelurahan, dilanjutkan di tingkat kecamatan, dikumpulkan berdasarkan urusan wajib dan pilihan pemerintahan daerah, dan selanjutnya diolah dan dilakukan prioritisasi program/kegiatan di tingkat kabupaten/kota oleh Bappeda bersama para pemangku kepentingan disesuaikan dengan kemampuan pendanaan dan kewenangan daerah.

\section{Reses}

Reses merupakan salah satu bentuk komunikasi politik, tidak saja terwujud dalam bentuk penyerapan aspirasi, penyampaian pengaduan dan gagasangagasan yang berkembang di daerah, melainkan juga penyampaian pertanggung jawaban anggota dewan terhadap konstituennya. Komunikasi yang baik dari anggota dewan dengan menjelaskan apa yang sudah dilakukan, bagaimana follow-up dari reses sebelumnya serta apa agenda strategis yang akan dilakukan kedepan dan yang terpenting adalah membangun opini serta kepercayaan konstituen dan publik terhadap kinerja dan pelaksanaan tugas fungsi anggota dewan sebagai wakil rakyat di parlemen.

Dasar Hukum Pelaksanaan reses Kabupaten Pesawaran :

1. Undang - Undang No. 17 tahun 2014 pasal 234 point (i) tentang Susunan Kedudukan Majelis Permusyawaratan Rakyat, Dewan Perwakilan Rakyat, Dewan Perwakilan Daerah, dan Dewan Perwakilan Rakyat Daerah. 
2. Peraturan Tata Tertib DPRD Kabupaten Pesawaran Nomor : 10 Tahun 2010.

Surat Keputusan Pimpinan DPRD Kabupaten Pesawaran, Nomor : 012/ DPRD-P/2-17, tanggal 06 Oktober tentang Pelaksanaan Reses III masa Persidangan III Tahun Sidang 2017.

\section{Analisa Serapan Pembangunan Berdasarkan Aspirasi Masyarakat}

Anggaran pendapatan dan Belanja Daerah (APBD) adalah rencana keuangan tahunan pemerintah daerah di Indonesia yang disetujui oleh Dewan Perwakilan Rakyat Daerah. APBD ditetapkan dengan Peraturan Daerah. Idealnya APBD merupakan susunan-susunan kegiatan yang merupakan aplikasi dari aspirasi masyarakat akan kesejahteraan dan kemajuan yang tertuang dalam pelaksanaan pembangunan melalui kebijakan Pemerintah Daerah yang disetujui bersama dengan DPRD.

Aspirasi masyarakat yang tertuang dalam APBD merupakan kolaborasi antar regulasi-regulasi dari Pemerintah Pusat, Pemerintah Provinsi dan Pemerintah Kabupaten yang memberi batasan-batasan hak dan wewenang daerah dalam pembangunan. Setiap akhir tahun anggaran Pemerintah Pusat melalui Mendagri menerbitkan Peraturan Menteri guna menjadi Pedoman daerah dalam penyusunan APBD tahun anggaran berikutnya.

\section{METODE PENELITIAN}

\section{Jenis Penelitian}

Penelitian yang dilakukan berupa studi kasus tentang proses penyusunan APBD Kabupaten Pesawaran Tahun Anggaran dan serapan aspirasi masyarakat melalui mekanisme Musrenbang dan Reses yang dilakukan Pemerintah Kabupaten Pesawaran.

\section{Lokasi Penelitian}

Penelitian dilakukan di kecamatankecamatan dan Organisasi Perangkat Daerah (OPD) pada Kabupaten Pesawaran yang dilaksanakan tahun 2018 yang melaksanakan Musrenbang dan Reses.

\section{Sampel}

Penelitian yang bersifat penelitian sampel hanya memilih sebagian dari subjek penelitian dan mengganggapnya mewakili keseluruhan. Pertimbangan yang diambil untuk tidak meneliti seluruh subjek mungkin karena keterbatasan biaya, tenaga, dan waktu atau mungkin memang tidak perlu melakukan hal demikian, karena dengan mengambil sebagian dari populasi sudah dapat mencerminkan sifat dari populasinya.

\section{Variabel dan Pengukuran}

Albert Waterston (1965) dalam "Development Planning", menyebutkan bahwa perencanaan pembangunan adalah: "melihat kedepan dengan mengambil pilihan berbagai alternatif dari kegiatan untuk mencapai tujuan masa depan tersebut dengan terus mengikuti agar supaya pelaksanaannya tidak menyimpang dari tujuan". Penetapan langkah-langkah yang strategis oleh pelaksana pembangunan juga sangat penting yang mendukung pelaksanaan kegiatan pencapaian tujuan pembangunan bisa tercapai dengan efektif dan efisien.

\section{Teknik Pengumpulan Data}


1. Metode Wawancara

Proses tanya jawab yang berlangsung secara lisan dan tatap muka, dengan Panitia Penyelenggaran Musrenbang Kabupaten dan Reses sebagai pelaksana sehingga data yang didapatkan mempunyai kesesuaian.

2. Penelitian Kepustakaan

Penelitian dilakukan dengan cara mempelajari literatur-literatur, jurnal, karya ilmiah dan buku-buku yang berhubungan dengan penulisan tesis ini.

\section{Observasi}

Penelitian yang dilaksanakan dengan cara melakukan pengamatanpengamatan pada proses pelaksanaan musrenbang dan reses dan pengaplikasian dalam APBD Kabupaten Pesawaran.

\section{Teknik Analisis Data}

Alat Analisis yang digunakan dalam penulisan tesis ini ialah:

1. Analisis Deskriptif Kualitatif

Analisis yang dilakukan dengan cara memaparkan data-data yang menggambarkan proses pelaksanaan Musrenbang dan Reses serta kendala yang menghambat pengaplikasian aspirasi masyarakat di penganggaran kegiatan dalam ABPD.

2. Analisis Akar Masalah

Analisis yang dilakukan dengan tujuan untuk mengidentifikasi masalahmasalah yang dalam menyebakankan serapan kegiatan yang tertuang dalam Musrenbang dan Reses tidak sesuai dengan Kegiatan yang terakomodir dalam APBD Kabupaten Pesawaran Tahun 2018.

\section{HASIL DAN PEMBAHASAN}

Penyerapan aspirasi masyarakat kedalam Anggaran Pendapatan dan Belanja Daerah Kabupaten Pesawaran, selain dari pembahasan dalam Musrenbang dan reses, namun juga terkait bagaimana aspirasi tersebut dapat tembus dalam pembahasan RAPBD dengan pihak legislatif adalah keterbatasan anggaran, kepentingan politik, dan kualitas usulan, hal ini lah yang menyebabkan munculnya bargaining dalam pembahasan RAPBD antara eksekutif dan legislatif.

Terkait hal-hal tersebut kegiatankegiatan yang dihasilkan dan dianggarkan dalam APBD merupakan kesepakatan bersama anggaran Bupati dan DPRD yang dihasilkan secara berjenjang. Jalur eksekutif melaksanakan Musrenbang Desa, Musrenbang Kecamatan, Musrenbang Kabupaten, hingga disahkan menjadi Peraturan Daerah APBD dan Peraturan Bupati tentang Penjabaran APBD. Sedangkan mekanisme legislatif atau DPRD melakukan Reses yang dilakukan sebanyak 3 kali setelah masa sidang dalam satu tahun.

Dalam APBD Kabupaten Pesawaran Tahun 2018 kegiatan-kegiatan pembangunan terutama fisik banyak merupakan hasil, dan masukan masyarakat melalui kegiatan musrenbang. Kegiatan yang teralokasi dalam Rencana Kerja Pemerintah Daerah (RKPD) Kabupaten Pesawaran Tahun Anggaran 2018 didominasi kegiatan-kegiatan yang merupakan masukan-masukan pada saat rapat Musrenbang Kabupaten yang dilaksanakan oleh Tim TAPD Kabupaten Pesawaran, hal ini dikarenakan kegiatan musrenbang merupakan rangkaian kegiataan dilaksanakan secara berjenjang, mulai Musrenbang Desa, Musrenbang Kecamatan dan diteruskan saat Musrenbang Kabupaten. Dalam musrenbang desa sudah dipilah dari usulan/aspirasi masyarakat berdasarkan prioritas yang telah dicantumkan sumber dananya berdasarkan 
kebutuhan dan bukan lagi keinginan dan disusun kembali sesuai dengan prioritas dan sumber dana pembangunan.

Setelah musrenbang desa dilanjutkan lagi dalam musrenbang kecamatan yang dalam pelaksanaanya dilakukan pemilahan atau koreksi kembali bersama dengan tim musrenbang kabupaten, petugas kecamatan (kasi PMD) dan melibatkan stakeholder berdasarkan sumber dana dan prioritas, hasil dibawa ke kabupaten untuk diverifikasi atau dipilah disesuaikan dengan RKPD dan visi misi (RPJMD) yang selanjutnya akan dalam dialokasikan kedalam renstra SKPD. Selanjutnya dalam forum SKPD seluruh satuan kerja yang menjadi tempat usulan atau pencantuman usulan kegiatan dalam Musrenbang hadir untuk melakukan rekonsiliasi antara petugas kecamatan dengan Pemerintah Kabupaten Pesawaran. Di dalam forum ini usulan akan dipilah dan diteliti secara teknis agar usulan tidak tumpang tindih dengan program yang akan dilaksanakan di kabupaten atau usulan itu sudah masuk dalam APBDesa, yang akan dituangkan dalam RKA (Rencana Kerja Anggaran). Rencana Kerja dan RKA SKPD disampaikan kembali kepada Bappeda yang kemudian akan dicantumkan dalam PPAS.

Musrenbang Kabupaten dihadiri legislatif yaitu anggota DPRD, eksekutif yaitu bupati dan seluruh SKPD, LSM, tokoh masyarakat, dalam Musrenbang tersebut dipaparkan lagi hasil-hasil musrenbang desa dan kecamatan yang telah dipilah sehingga jenis-jenis kegiatan yang dibiayai APBN melalui Bappenas dan Bappeda Provinsi dan mana yang masuk dana APBD Kabupaten melalui SKPD terkait pada Kabupaten Pesawaran. Setelah pemantapan melalui tahapan-tahapan di atas didapatlah hasilnya yang tertuang dalam KUA-PPAS dan kemudian disampaikan kepada DPRD.

Sedangkan pelaksanaan penyerapan aspirasi masyarakat melalui mekanisme reses merupakan bagian lainnya dari kegiatan-kegiatan yang diakomodir dalam APBD Kabupaten Pesawaran, hal ini disebabkan pelaksanaan reses yang dilakukan oleh legislatif atau anggota DPRD dilakukan menyesuaikan berakhirnya masa sidang yang waktunya temtatif dan menyesuaikan. Sehingga sebagian masyarakat mengganggap 38 penyampaian aspirasi kegiatan reses merupakan ajang penyampaian aspirasi atau keinginan masyarakat yang belum terakomodir dalam dokumen yang diajukan dalam musrenbang desa atau kecamatan sehingga kegiatan-kegiatan yang hadir sebagai output dari reses kurang maksimal.

Hal lainnya yang menyebabkan aspirasi atau masukan dari masyarakat melalui reses sangat minim adalah waktu pelaksanaan reses yang sangat singkat yakni hanya 2 (dua) hari setiap daerah pilih (dapil). Dengan waktu pelaksanaan reses yang hanya 2 hari dan melibatkan seluruh stakeholder/pemangku kepentingan banyak sekali hal-hal yang sebenarnya diperlukan oleh masyarakat dan belum disampaikan dalam kegiatan musrenbang namun tidak tersampaikan juga dalam kegiatan reses.

Usulan masyarakat (aspirasi) yang disampaikan masyarakat dalam reses biasanya disampaikan pemuka adat, tokoh masyarakat, tokoh pemuda, dan lingkungan Rukun Tetangga yang terwakilkan melalui Ketua Rukun Tetangga (RT), sedangkan dari sisi pemerintahan diwakili oleh Kepala Pekon, Lurah, Camat, UPT-Puskesmas dan UPT Pertanian. Dalam penyampaianya aspirasi yang disuarakan oleh masyarakat terkadang tidak sistematis dan tertata serta hal ini dipengaruhi latar belakang pendidikan yang rendah sehingga redaksional yang digunakan adalah bahasa daerah yang kurang dipahami atau bahasa istilah yang berlaku di daerah tertentu.

Sebagai sebuah kabupaten pemekaran, Kabupaten Pesawaran sedang membangun perekonomian yang mapan hal ini dapat 
terlihat dari banyaknya keinginan masyarakat untuk mendirikan pasar-pasar rakyat untuk meningkatkan kesejahteraannya, serta keinginankeinginan untuk meningkatkan fasilitasfasilitas pendukung UMKM yang dapat disediakan oleh pemerintah kabupaten. Tidak secara bersamaan pembangunan itu dapat dilaksanakan, selain telah ditetapkannya APBD Kabupaten Pesawaran Tahun Anggaran 2018 yang artinya pagu dan kegiatan yang akan dilaksanakan sudah jelas tercantum.

Alternatif lain yang dapat dilakukan Pemerintah Kabupaten Pesawaran melalui Tim TAPD ialah mengalokasikan beberapa pembangunan fisik pasar rakyat dalam perubahan APBD Tahun Anggaran 2018, hal ini juga dengan dilakukan dengan seksama memperhatikan besaran Sisa Lebih Perhitungan Anggaran (Silpa). Silpa adalah sisa lebih perhitungan anggaran tahun anggaran yang lalu, yang merupakan dana sisa yang dapat dialokasikan kembali sesuai dengan hasil Laporan Kinerja dan Pertanggungjawaban Keuangan yang disusun dan diajukan oleh Bupati melalui TAPD Kabupaten Pesawaran kepada Anggota DPRD. Dana inilah yang akan membiayai kegiatan-kegiatan penting yang belum teranggarkan dalam APBD Tahun 2018.

Silpa yang terbatas ini tidak dapat memenuhi semua harapan dan aspirasi masyarakata yang artinya tidak akan mengakomodir secara menyeluruh sisa kegiatan yang belum dialokasikan dalam APBD Tahun Anggaran 2018, mengingat keterbatasan tersebut TAPD harus berhatihati mengalokasikannya dengan berkonsolidasi dengan seluruh stakeholders, dan perlunya penataan kembali prioritas pengalokasian Silpa yang ditetapkan dalam KUA-PPAS Perubahan APBD, untuk memenuhi unsur legal formal penyerapan aspirasi stakeholders serta memenuhi harapan masyarakat, dan menyusun sisa kegiatan yang belum teranggarkan pada tahun anggaran 2018 sebagai prioritas pada tahun anggaran 2019.

Hal lain yang mempengaruhi tidak terakomodirnya kegiatan pembangunan dalam APBD dibiayai dengan dana alokasi khusus (DAK) yang alokasi terbatas yang ditetapkan oleh Peraturan Menteri Keuangan tentang Alokasi DAK. Banyaknya permintaan masyarakat dalam pembangunan insfrastuktur dalam satu kecamatan yang sama di Kabupaten Pesawaran mengharuskan Tim TAPD harus melakukan seleksi ketat dalam menentukan prioritas pelaksanaan pembangunan dikecamatan, memilih kegiatan yang memiliki manfaat langsung kepada masyarakat tapi juga mengakomodir keinginan para stakeholder. Karena dalam mengambil keputusan menetapkan suatu kegiatan disuatu lokasi Tim TAPD harus mempertimbangkan banyak faktor mulai alokasi DAK, manfaat langsung kegiatan pada masyarakat, hingga kepentingan eksternal stakeholder.

Aspirasi masyarakat dalam pembangunan di Kabupaten Pesawaran didominasi dengan perbaikan sarana pendidikan seperti sekolah baru, ruang kelas baru dan perbaikan sarana dan pra sarana pendidikan hal ini didorong keinginan peningkatan sumber daya manusia pesawaran serta mendukung program pembangunan nasional. Keinginan lain yang diajukan masyarakat melalui musrenbang dan reses ialah pembangunan dan perbaikan infrastruktur, terutama pembangunan yang dapat menghubungkan antar daerah dengan jarak tempuh yang lebih cepat yaitu dengan percepatan pembangunan jalan baik peningkatan kualitas jalan yang menghubungkan antar desa dan antar kecamatan serta pembukaan akses jalan baru yang lebih strategis yang pada akhirnya diharapkan dapat meningkatkan kuakitas hidup masyarakat. 
Mata pencaharian masyarakat Kabupaten Pesawaran yang dominan bertani juga mengharapkan pengairan yang baik dan cukup untuk memaksimalkan hasil tanam, perbaikan irigasi serta normalisasi aliran sungai diharapkan dapat menjadi solusi yang baik didukung dengan pengadaan bibit untuk serta pasokan pupuk yang memadai.

Pembangunan-pembangunan tersebut merupakan kegiatan pembangunan daerah yang sesuai dengan prioritas pembangunan nasional sehingga pendanaannya dapat dilakukan melalui pengajuan Dana Alokasi Khusus (DAK) dari jenis dan bidang DAK yang sudah ditentukan. Namun penggunaan dana DAK yang bersifat nasional membutuhkan pendampingan khusus oleh pemerintah mulai dari penyusunan pengajuan atau proposal DAK hingga penyampaian ke tingkat kementerian terkait, hal ini wajar dilakukan karena minimnya suplai dana DAK. Hal lainnya ialah pelaksanaan reses III masa persidangan 3 Tahun Sidang 2017 DPRD Kabupaten Pesawaran dilaksanakan pada Triwulan IV tahun 2017 yaitu pada tanggal 16 - 17 Oktober 2017, yang berarti mekanisme penyusunan APBD untuk tahun anggaran 2018 sudah dijalankan.

Guna menjalankan fungsi budgeting / penganggaran penyerapan aspirasi yang dilakukan melalui reses oleh anggota DPRD merupakan langkah strategis dalam mendukung pembangunan, mempererat komunikasi dengan eksekutif dan menyentuh langsung konstituen yang menjadi prioritas. Dengan luas wilayah yang 1.773,77 Km2 dan 11 kecamatan serta meliputi 144 desa, maka penyerapan asrpirasi melalui mekanisme reses yang hanya dilakukan selama 2 hari sangatlah tidak maksimal. Meskipun dalam prosesnya pelaksanaan reses oleh DPRD yang di fasilitasi oleh Sekretariat DPRD Kabupaten Pesawaran berusaha merangkul semua aspek-aspek yang melibatkan kebutuhan masyarakat, dengan mengundang seluruh pihak yang dapat mencerminkan representasi "wajah" dan keinginan masyarkat pada daerah pilih.

Kendala komunikasi juga mempengaruhi masukan-masukan yang disampaikan masyarakat dalam dialog tatap muka dengan anggota DPRD. Masyarakat yang secara kultural memposisikan anggota dewan pada strata masyarakat yang lebih tinggi membuat sebagian masyarakat canggung dan segan menyampaikan aspirasi dan ide dalam forum resmi. Konsep pelaksanaan reses yang diatur sesantai mungkin, untuk memperkecil jarak status sosial antara Anggota DPRD dan Masyarakat sehingga diharapkan komunikasi yang terjalin bisa lebih harmonis dan berkesan kekeluarga, sehingga keluhan-keluhan, keinginankeinginan dan harapan-harapan masyarakat akan pembangunan di Kabupaten Pesawaran dapat tersampaikan yang akhirnya diharapkan dapat direalisasikan dalam pembangunan.

\section{KESIMPULAN DAN SARAN}

\section{Kesimpulan}

Berdasarkan hasil penelitian dapat disimpulkan hasil penelitian ini adalah :

1. Aspirasi masyarakat atau stakeholders melalui musrenbang telah terserap dalam APBD, jumlah masukan yang diajukan masyarakat melalui mekanisme musrenbang sebanyak 658 kegiatan dan telah dianggarkan dalam APBD Tahun anggaran 2018 sebanyak 410 Kegiatan atau $62.3 \%$, sisa kegiatan yang tidak atau belum terakomodir dalam APBD Tahun Anggaran 2018 sebanyak 245 Kegiatan atau $37,7 \%$. Kegiatan yang tidak terakomodir merupakaan kegiatan kegiatan yang tidak / bukan merupakan kewenangan daerah Kabupaten 
Pesawaran, sehingga perlu dilakukan koordinasi dan registrasi kegiatan antar Kabupaten dengan Provinsi dan Kabupaten dengan Pemerintah Pusat guna penganggaran kegiatan dalam DAK tahun berikutnya.

2. Aspirasi masyarakat atau stakeholders melalui Reses telah terserap dalam APBD, jumlah masukan yang diajukan masyarakat melalui mekanisme Reses sebanyak 93 kegiatan dan telah dianggarkan dalam APBD Tahun anggaran 2018 sebanyak 35 Kegiatan atau $38,46 \%$, sisa kegiatan yang tidak atau belum terakomodir dalam APBD Tahun Anggaran 2018 sebanyak 248 Kegiatan atau $62,54 \%$. Jenis kegiatankegiatan yang belum/tidak teranggar dalam APBD Tahun Anggaran 2018 dikarenakan jenis kegiatan yang diajukan melalui mekanisme reses merupakan kegiatan fisik Dana Alokasi Khusus (DAK) yang memerlukan mekanisme pengajuan kegiatan ke kementerian terkait.

\section{Saran}

Berdasarkan hasil penelitian tersebut dapat dikemukan beberapa saran sebagai masukan bagi Pemerintah Kabupaten Pesawaran dan DPRD Kabupaten Pesawaran penulis menyarankan hal-hal sebagai berikut :

1. Penyusunan mekanisme pendamping Musrenbang dan Reses secara non formal guna mendapatkan masukanmasukan masyarakat yang menunjang kesejahteraan sebagai tujuan pembangunan, hal ini dimungkinkan karena ide-ide spontan masyarakat terkadang timbul dari komunikasi non formal, santai dan bersifat kekeluargaan.

2. Penyediaan fasilitas-fasilitas untuk menyampaikan pendapatan diluar jalur formal misalnya SMS center, WA untuk masyarakat, Kontak Aspirasi dan phone center.

3. Penyampaian naskah musrenbang kecamatan pada saat reses sehingga dokumen yang dimiliki eksekutif dan legislatif tidak terdapat ketimpangan atau ketidak sesuaian yang memerlukan diskusi panjang dalam penyelesaiannya.

\section{DAFTAR PUSTAKA}

Ayi, K. \& Siti A. 2012. Pengorganisasian Musyawarah Perencanaan Pembangunan Desa di Desa Kalongsawah Kecamatan Jasinga Kabupaten Bogor. Jurnal Organisasi dan Manajemen, Volume 7, Nomor 2, September 2011, 140-156.

Bastian, Indra. 2006. Sistem Perencanaan dan Penganggaran Pemerintahan Daerah di Indonesia. Jakarta: Salemba Empat.

Bungin, Burhan. 2008. Penelitian Kualitatif: Komunikasi, Ekonomi, Kebijakan Publik, dan Ilmu Sosial Lainnya. (6th Ed.). Jakarta: Kencana.

Davis, Keith. 1985. Perilaku Dalam Organisasi. Jakarta: Erlangga.

Faisal, Nur. 2011. "Partisipasi Masyarakat Dalam Proses Pembangunan Infrastruktur Desa (studi kasus : Program Alokasi Dana Desa di Desa Bilao Kabupaten Bulukumbang)". Jurnal Program Pascasarjana UNHAS 04-02-2011.

Nurcholis. 2005. Teori dan Praktek Pemerintahan dan Otonomi Daerah. Jakarta: Grasindo.

Pesawaran, Bappeda, 2015. Pesawaran Dalam Angka. 
Riyadi dan Dedi Supriadi Bratakusumah. 2004. Perencanaan Pembangunan Daerah Strategi Menggali Potensi dalam Mewujudkan Otonomi Daerah. Jakarta: PT Gramedia Pustaka Utama.

Sjafrizal. (2009). Teknik Praktis Penyusunan Rencana Pembangunan Daerah. Padang: Baduose Media.

Sunarti. 2003. Partisipasi Masyarakat dalam Pembangunan Perumahan secara Kelompok. Jurnal Tata Loka. Semarang: Planologi UNDIP.

Syafiie, Kencana, Inu, Drs. 2002. Sistem Pemerintahan Indonesia. PT. Rineka Cipta. Jakarta.

Syaifullah. 2007. Tesis Analisa Kebijakan Perencanaan Pembangunan Tahunan di Kota Magelang.

Sutarti, Nurul. (2013). "Mendorong partisipasi perempuan dalam proses demokrasi lokal di kota surakarta: sebuah pengalaman pendampingan kelompok perempuan dalam proses musrenbang". 07 Jurnal KS, 4034884.

Undang-Undang Republik Indonesia Nomor 25 Tahun 2004 Sistem Perencanaan Pembangunan Nasional. Tanggal Pengesahan. Lembaran Negara Republik Indonesia Tahun 2004 Nomor 104, Dan Tambahan Lembaran Negara Republik Indonesia Nomor 4421. Jakarta.

Undang-Undang Republik Indonesia Nomor 32 Tahun 2004 tentang Pemerintahan Daerah. 15 Oktober 2004, Lembaran Negara Republik Indonesia Tahun 2004 Nomor 125.

Undang - Undang No. 17 tahun 2014. pasal 234 point (i) tentang Susunan Kedudukan Majelis Permusyawaratan
Rakyat, Dewan Perwakilan Rakyat, Dewan Perwakilan Daerah, dan Dewan Perwakilan Rakyat Daerah.

Waterston, Albert 1965. Development Planning Lessons of Experience. The Johns Hopkins, University Press Baltimore and London

Winarno, Budi. (2002). Teori dan Proses Kebijakan Publik. Yogyakarta: Media Presindo. 